\title{
Molecular Aspects of Membrane Trafficking in Paramecium
}

\author{
Helmut Plattner and Roland Kissmehl \\ Department of Biology, University of Konstanz, D-78457 Konstanz, Germany
}

Results achieved in the molecular biology of Paramecium have shed new light on its elaborate membrane trafficking system. Paramecium disposes not only of the standard routes (endoplasmic reticulum $\rightarrow$ Golgi $\rightarrow$ lysosomes or secretory vesicles; endo- and phagosomes $\rightarrow$ lysosomes/digesting vacuoles), but also of some unique features, e.g. and elaborate phagocytic route with the cytoproct and membrane recycling to the cytopharynx, as well as the osmoregulatory system with multiple membrane fusion sites. Exocytosis sites for trichocysts (dense-core secretory vesicles), parasomal sacs (coated pits), and terminal cisternae (early endosomes) display additional regularly arranged predetermined fusion/fission sites, which now can be discussed on a molecular basis. Considering the regular, repetitive arrangements of membrane components, availability of mutants for complementation studies, sensitivity to gene silencing, and so on, Paramecium continues to be a valuable model system for analyzing membrane interactions. This review intends to set a new baseline for ongoing work along these lines.

KEY WORDS: Ciliates, Membranes, Membrane traffic, Membrane fusion, Paramecium.

\section{Introduction}

Membrane trafficking has manyfold facets. It includes budding of vesicles ("fission"), in contrast to vesicle docking and membrane fusion, and, furthermore, intracellular transport, including membrane recycling (Kirchhausen, 2000). A plethora of details is known, particularly from yeast and mammalian systems, although many important aspects still remain 
to be elucidated, such as the simple sounding question: which molecules form the pore during membrane fusion? Or the more intriguing question: how are specific pathways of membrane trafficking predetermined?

Over the years, ciliated protozoa, such as Paramecium and Tetrahymena, have served as model systems for many aspects of cell biology (Plattner, 2002; Turkewitz et al., 2002), although molecular information just on membrane trafficking now lags behind other systems. Therefore, frequently only a cursory discussion of certain aspects has been possible in the past, although some specific advantages (outlined in the following paragraph) of these ciliated protozoa make them most appropriate to address some specific questions.

For several reasons, this review concentrates on Paramecium as a model system: (i) This cell disposes of a regular "design" (Plattner, 2002); (ii) this marks several routes not so overt in other ciliated protozoa; (iii) many more analyses on membrane traffic have been executed with this cell than in other ciliates; (iv) an international Paramecium genomics project (Dessen et al., 2001; Speeling et al., 2002) has delivered new molecular details; (v) while the basic machinery for membrane-to-membrane interactions, i.e., docking and fusion, can now safely be assumed to be the same in Paramecium as in "higher" eukaryotes, additional proteins, not previously known from other cells, have been found; (vi) Paramecium is also attractive to study molecular diversification inside one cell; and (vii) reliable molecular information on this ciliated protozoan becomes increasingly available. The newly started Tetrahymena genome project (Turkewitz et al., 2002) may allow a stimulating comparison with basic findings from the rapidly progressing Paramecium project, which steadily develops in the direction of proteomics.

Membrane trafficking can encompass transport, docking, fusion, and fission. The latter is a process forming two compartments from one. Membrane fusion appears much more complicated and requires recognition of the partners to be fused, i.e., specific docking, before final fusion. The different pathways of membrane trafficking occurring in a Paramecium cell are outlined in Fig. 1. Molecular details known so far are summarized in Table I.

For different types of membrane fusion in higher eukaryotes, it is now well established that the molecular machinery, including $N$-ethylmaleimidesensitive factor (NSF)/soluble NSF attachment proteins (SNAP)/SNAP receptor (SNARE) proteins, governs membrane-to-membrane interactions by forming pin-like mechanical links between adjacent membranes to clamp them together and, thus, to prepare them for fusion (Söllner et al., 1993a,b; Rizo and Südhof, 1998; Jahn and Südhof, 1999; Jahn and Grubmüller, 2002; Martin, 2002; Mayer, 2002). NSF in a structure-bound form is an ATPase that acts as a SNARE-specific chaperone (Whiteheart et al., 2001). It thus allows to bring SNAREs in an appropriate position, i.e., to form pins 


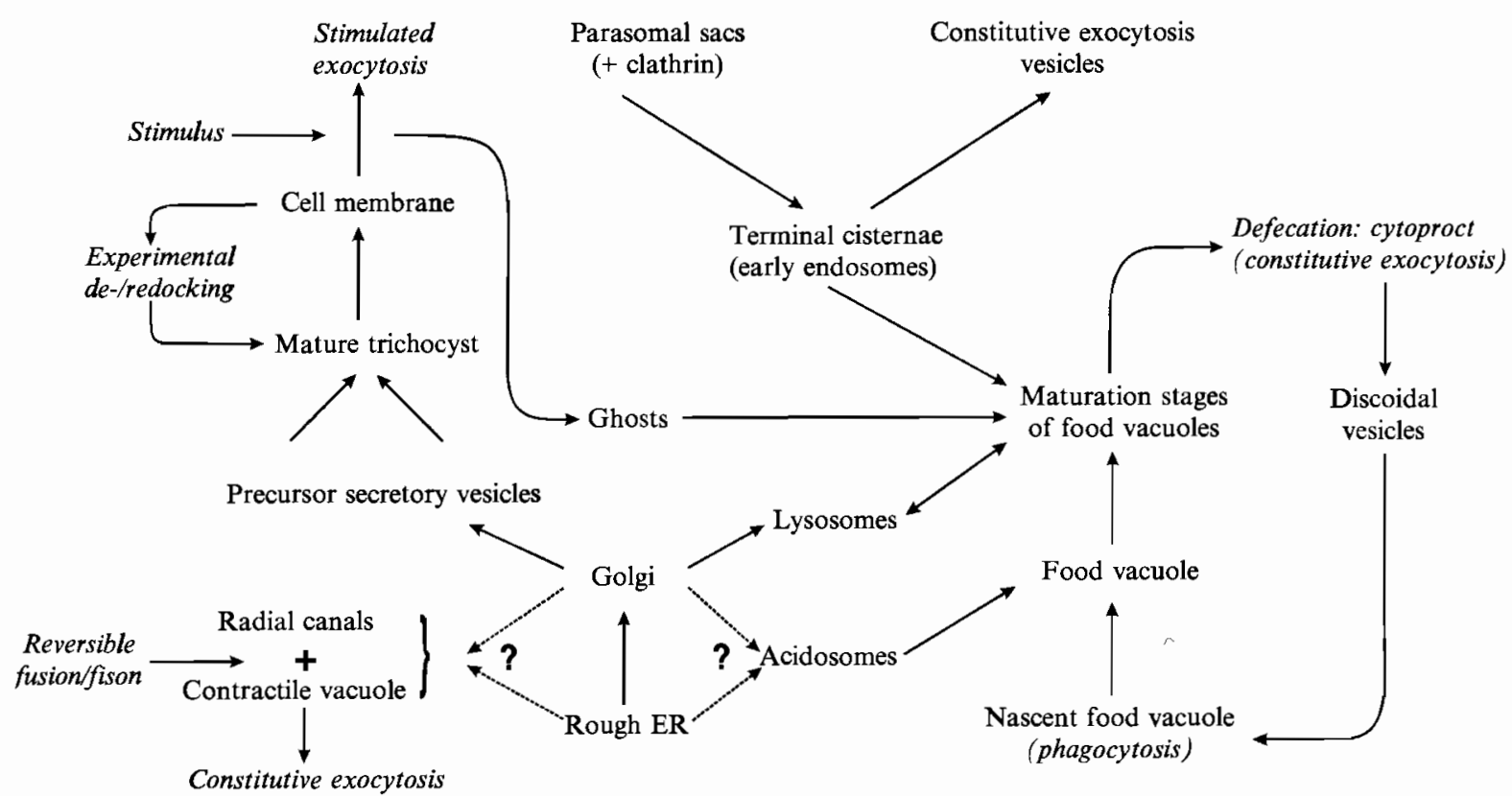

FIG. 1 Scheme of the main membrane trafficking routes in Paramecium, including different routes of vesicular transport, vesicle docking, and fusion, as well as vesicle fission. Omitted are minor routes, such as some aspects of the endo/phago/lysosomal system, and aspects of the biogenesis of organelles, such as alveolar sacs. For further comments, see text. 
TABLE I

Gene Products, Relevant for Membrane Trafficking in Paramecium, for which Genes Are Known with EMBL Data Bank Accession Numbers Indicated ${ }^{a}$

\begin{tabular}{|c|c|c|}
\hline Gene product & Trafficking steps & Availability (accession \#) \\
\hline \multicolumn{3}{|l|}{ Adaptor proteins } \\
\hline AP1 & TGN $\rightarrow$ lysosomal budding & Partial sequences, confidential (available soon) \\
\hline AP2 & Endocytosis & Confidential (available soon) \\
\hline AP3 & Endosomes & PT006K 15R \\
\hline AP4 & TGN/endosomes/lysosomes & PT017M05R \\
\hline $\begin{array}{l}\mathrm{ARF}^{b} / \mathrm{SAR} \text { (monomeric } \\
\text { G-protein) }\end{array}$ & Golgi, etc. (brefeldin A target) & Several sequences, confidential (available soon) \\
\hline Calcineurin (PP2B) & Endocytosis & \\
\hline A-SU ${ }^{c}$ (catalytic) & & AF014922, AJE67906 and confidential sequences (available soon) \\
\hline B-SU (regulatory) & & AJ554047, AJ554048 * \\
\hline Calmodulin & Different steps & M34540, further sequences confidential (available soon) \\
\hline Clathrin, heavy chain & $\begin{array}{l}\text { Different steps, including endocytosis } \\
\text { and lysosome budding }\end{array}$ & PT008K05R, PT014115U \\
\hline Coatamer proteins & ER $\rightarrow$ Golgi, intra-Golgi & \\
\hline$\alpha-\mathrm{COP}$ & & PT017G21U \\
\hline Other COPs & & Confidential sequences (available soon) \\
\hline Regulators of monomeric & Different steps of trafficking & \\
\hline \multicolumn{3}{|l|}{ G-proteins } \\
\hline $\begin{array}{l}\text { GAP (guanine nucleotide } \\
\text { activation proteins) }\end{array}$ & & AF129515, several confidential sequences \\
\hline $\begin{array}{l}\text { GEF (guanine nucleotide } \\
\text { exchange factors) }\end{array}$ & & Several sequences, confidential (available soon) \\
\hline
\end{tabular}


$\mathrm{H}^{+}$-ATPase

$V_{0}$ proteolipid part

a-SU ( $V_{0}$ associated)

nd2

nd7

nd9

NSF

Rab-type monomeric

G-proteins

$\vec{D} \quad$ Rho-type monomeric

G-proteins

\section{SNARE}

Synaptobrevin

Synaptojanin
Potential fusion mediator

Integration of catalytic SU

Stimulated exocytosis

Stimulated exocytosis

Stimulated exocytosis

General membrane docking

Different potential steps

Different potential steps

Docking/fusion

Endocytosis
PT001A13R, AL446850, AJ566616 to 566619

PT007I19U*, AJ538330*

(available soon)

AJ437480

Y07803

AJ293945

AJ347751*, AJ347752*, PT009A07R

Numerous sequences, mainly depostied by $D$. Fraga and B. Hinrichsen; see EMBL data bank for details.

Further sequences still confidential

U03615, U03617, further sequences confidential

(available soon)

PT018K05U, PT018009R, AJ566288 to 566301* PT020M01R

a"Confidential" means sequences from this and other laboratories, including the International Paramecium Genome Project and GDRE (information available via the internet address indicated in the text) deposited in the EMBL data bank at this time, to be disclosed at the latest publication of this review. Not included are sequences from components of the cytoskeleton and motor proteins, from signaling components, ion channels and a variety of ion pumps. which would be of indirect relevance for membrane trafficking. PT signatures are mainly partial sequences; sequences established in this laboratory are labeled by asterisk, with all sequences being available soon.

${ }^{b}$ Adenosine ribosylation factor.

'Subunit. 
between adjacent membranes. NSF is an AAA-type ATPase (Neuwald et al., 1999), which is released upon ATP hydrolysis (Littleton et al., 2001). Once established, SNARE pins are resistant to disruption by NSF and the SNAP protein, type $\alpha$ SNAP (Weber et al., 2000). SNAREs are considered relevant actors not only in docking, but, by some authors, also in membrane fusion (Nickel et al., 1999). Alternatively work has assigned this function to secretory carrier membrane proteins (SCAMPS) (Brand and Castle, 1993; Liu et al., 2002). Some time ago, there was indirect evidence of the relevance of the lipoprotein basepiece, $V_{0}$ (cf. Wilkens, 2001), of a $\mathrm{H}^{+}$-ATPase in neurotransmitter release (Morel et al., 1991). Latest developments envisage this molecular component as a fusogen when present without the $\mathrm{H}^{+}$-pumping catalytic part so that matching pairs in adjacent membranes could closely approach each other and serve this function (Mayer, 2001; Peters et al., 2001). Also, in yeast, $V_{0}$ and SNAREs are connected via a Vtc protein (Müller et al., 2002).

At this time, actual fusogenic proteins are not yet established with any precision in most systems and, therefore, are still a matter of intense debate (Zimmerberg, 2001; Jahn and Grubmüller, 2002). Nevertheless, the involvement of NSF, SNAPs, and SNAREs in mediating membrane-to-membrane contacts is widely accepted. All models operate with molecules arranged side by side, in both of the membranes to interact. In the case of SNAREs, they are designated as $\mathrm{v}$ or $\mathrm{t}$ type, e.g., during exocytosis, depending on whether they occur on the vesicle membrane or on the the cell membrane as the target membrane (Söllner et al., 1993a,b; Söllner and Rothman, 1994). Synaptobrevin and cellubrevin are v-SNAREs, SNAP-25 and syntaxin are t-SNAREs. Monomeric "small" GTP-binding proteins (G-proteins) also participate in vesicle docking (Rothman and Söllner, 1997; Takai et al., 2001).

Exocytosis sites in Paramecium are ultrastructurally clearly defined microdomains (Plattner, 1987, 2002; Vayssié et al., 2000). A concept envisaging the microdomain arrangement of SNAREs at exocytosis sites slowly emerges also in mammalian systems (Chamberlain et al., 2001; Lang et al., 2001). While synaptotagmin is an established $\mathrm{Ca}^{2+}$ sensor during stimulated exocytosis (Sugita et al., 2002; Tucker and Chapman, 2002), it also participates in some internal membrane fusion processes that it modulates (Grimberg et al., 2003).

When vesicles pinch off, a molecular machinery that is rather different from the NSF/SNAP/SNARE complex is engaged (Section IV,B,1). Different "coat protein complexes" help collect the proper components in vesicles to be formed (Nickel and Wieland, 1997; Kirchhausen, 2000; Malkus et al., 2002; Yang et al., 2002; Gundelfinger et al., 2003). Pinching off is mediated by the monomeric G-protein, dynamin to which different auxiliary proteins are coassembled. These aspects are discussed in more detail in the respective sections. 


\section{Paramecium: A Cell with Elaborate Routes of Intense Membrane Traffic}

\section{A. Value as a Model System}

Functional and (ultra)structural features of membrane trafficking and some of the membrane-to-membrane interaction sites in Paramecium have been analyzed thoroughly (Allen, 1988; Görtz, 1988; Plattner, 1993) before molecular biology became available as a tool for this organism. Some aspects, like the organization of trichocyst docking sites, are so prominent that some time ago, in connection with classical genetic (Beisson et al., 1976) and dynamic ultrastructural studies (Knoll et al., 1991), this system delivered novel hints to important determinants for vesicle docking and membrane fusion. It then served to establish new models of these basic phenomena (Plattner, 1987, 2002; Plattner and Kissmehl, 2003). Another aspect of membrane trafficking with impact on work with "higher" eukaryotes dealt with the digestive cycle (Allen and Fok, 1993a, 2000). This work also revealed novel aspects, such as phagosome acidification by dedicated organelles, the acidosomes (Allen and Fok, 1983). Nonetheless, molecular details governing membrane interactions have remained elusive with this system until recently, while a number of laboratories analyzing mainly yeast and mammalian cells achieved great progress at the molecular level.

\section{B. Recent Molecular Approaches to the Study of Membrane Trafficking}

Until recently, information on molecular details was available for Paramecium only to a limited extent (Kung et al., 2000), although some additional molecules previously unknown from mammalian cells had been identified as determinants of some aspects of membrane trafficking (Vayssié et al., 2000). On the basis of an indexed genomic library with $\sim 60,000$ macronuclear DNA clones (Keller and Cohen, 2000), the group of Jean Cohen (CNRS, Gif-surYvette) initiated an international Paramecium genome project (Dessen et al., 2001), which delivers a steadily increasing number of sequences, including some relevant for basic aspects of membrane trafficking (Table I). It allows us to design appropriate primers and to clone the respective genes.

Cloning of the Paramecium NSF gene, in collaboration with the Cohen group, was a pivotal step (Froissard et al., 2002; Kissmehl et al., 2002). Because NSF is a chaperone for SNAREs and because these interact with additional components, this now opens the door to many other components of the docking/fusion machinery. Such work allows us to predict 
immunogenic sites and, with the monospecific antibodies (ABs) thus produced, we can proceed to the proteomics aspect.

(Ultra)structural localization studies depend greatly on technical achievements. For NSF, this is particularly intriguing because it is bound only transiently to sites of membrane interaction and then released. For LM fluorescence, we have therefore carefully permeabilized cells in the presence of NEM and the nonhydrolyzable ATP analogue, ATP- $\gamma-S$ (which keeps NSF in place) under conditions allowing the cells to survive before they were exposed to anti-NSF ABs (Kissmehl et al., 2002). Gene silencing involved macronuclear injection of a number of open reading frames (ORFs) of the NSF gene, followed by single cell processing for EM analysis (Froissard et al., 2002).

We now see that in many molecules of interest, sequence homologies may be due to widely scattered amino acids rather than to large motifs. Therefore, in retrospect, we now understand why, using ABs available from other systems, previous attempts to identify proteins relevant to membrane trafficking have consistently failed. With exceptions, this also requires adequate scepticism toward localization studies using ABs against heterologous proteins in a variety of ciliated protozoa, unless specificity has been documented with particular care. Molecular biology has turned out to be a mandatory prerequisite for any further functional and structural work.

\section{Established Membrane Trafficking Routes}

Cotranslational sequestration of proteins in the rough endoplasmic reticulum (ER) for transport to the Golgi complex and subsequent delivery to lysosomes or to "clear secretory vesicles" for constitutive (nonstimulated) exocytosis belong to the standard repertoire of eukaryotic cells, including Paramecium (Allen, 1988; Görtz, 1988) and other protists (Plattner, 1993). In addition, these cells also produce dense-core secretory vesicles ("trichocysts") for stimulated exocytosis (Adoutte, 1988; Plattner et al., 1993). A rather intriguing vesicle trafficking system is represented by the digestive cycle, including the formation of phagosomes ("food vacuoles") and their further processing (Fok and Allen, 1993; Allen and Fok, 2000). Finally, the osmoregulatory system, normally present in two copies, involves membrane trafficking "on the spot," i.e., repeated multiple membrane fusions and fissions without any large-scale movements (Allen, 2000; Allen and Naitoh, 2002).

Many of these membrane-to-membrane interaction sites are predetermined structurally in Paramecium. This is true for the sites of phagosome formation in the "cytostome"/"cytopharynx" area (Allen, 1988; Fok and Allen, 1993; Allen and Fok, 2000), the release site for spent phagosomes at 
the "cytoproct" (Allen and Wolf, 1974), for the reversible attachment sites of radial canals to the two "contractile vacuoles" and for their outlets at the cell surface (Tominaga et al., 1998), as well as for the constitutive exo/ endocytosis sites ("parasomal sacs") located close to ciliary origins (Allen et al., 1992), as well as for the docking/release sites of trichcocysts (Pape and Plattner, 1995; Pouphile et al., 1986; Vayssié et al., 2000).

\section{Standard Route: Endoplasmic Reticulum to Golgi Complex and Further On}

A wealth of molecular details is known on membrane trafficking in higher eukaryotes, including integral and membrane-associated proteins, as well as temporary coats for specific budding processes (Kirchhausen, 2000). Only circumstantial evidence is available in Paramecium for this obvious route. The presence of a $61-\mathrm{kDa}$ protein with immunoreactivity with $\mathrm{ABs}$ against mammalian calreticulin-ABs in the ER of Paramecium (Plattner et al., 1997b) suggests a $\mathrm{Ca}^{2+}$ - and glycosylation-dependent chaperone function, based on data from other cells (Leach et al., 2002; Schrag et al., 2003). The same holds for a calnexin homolog and for some disulfide isomerases whose genes have been cloned (D. Geissinger, R. Kissmehl, H. Plattner, AJ567915, AJ567916). Glycosylphosphatidylinositol (GPI)-anchored variant surface antigens (svAGs) are abundantly synthesized in Paramecium (Capdeville, 2000), a process known to take place also in the ER (Ferguson, 1999). Other prominent ER products comprise precursor proteins of trichocyst content, the pretrichynins (Gautier et al., 1994, 1996), not to speak of any other components generally derived from ER.

Different proteins are probably transported to the Golgi complex by vesicles coated with coatamer proteins (COPs) as molecular filters, notably "coat protein complex II," COPII (Nickel and Wieland, 1997; Malkus et al., 2002). Although basic details are not known in Paramecium, the occurrence of COPs is quite certain because of the EM appearance of such coats (see later) and because at least one fragmentary gene sequence of one type of COP is known (Table I).

A Paramecium cell contains a large number, probably several hundred, of Golgi fields, each of small size (Estève, 1972; Allen, 1988). The same holds true of Tetrahymena (Kurz and Tiedtke, 1993). This may explain why the rather simple task to identify these organelles by specific fluorescent labeling has not been accomplished to any satisfactory extent. Using ABs against the Golgi-specific (clathrin-)adaptor protein type AP1 (Traub et al., 1995), we saw numerous punctate internal labeling sites, which disappeared with brefeldin A, although at relatively high concentration (M. Momayezi and 
H. Plattner, unpublished observations). This agent causes Golgi breakdown (Nebenführ et al., 2002) by interfering with binding of the monomeric G-protein, type ARF, which normally mediates vesicle delivery. Partial sequences of ARF are available from Paramecium (Table I). In addition, in mammalian cells, AP1 is engaged in vesicle traffic from the trans-Golgi network (TGN) to endocytotic vesicles and back to the TGN (Hinners and Tooze, 2003). COPI-type proteins would be additional markers (Nickel and Wieland, 1997; Yang et al., 2002), whereas "standard" Golgi markers gave no signal (unpublished observation). For AP1 and COPs, see Table I. Definitely more molecular work is needed to identify the Golgi complex on the light microscope level in future studies on membrane dynamics. This is also mandatory to understand the budding of primary lysosomes in Paramecium on the basis of the respective auxiliary molecules, such as AP1 and COPI. Considering detailed knowledge available from other eukaryotes (Urbé et al., 1997; Avran and Castle, 1998), much remains to be analyzed with ciliates.

Some of the trichocyst content components are glycosylated, probably including core and peripheral glycosylation (Lüthe et al., 1986; Allen et al., 1988; Glas-Albrecht et al., 1990). For the "mesh-like sheath," a structure connecting the paracrystalline secretory matrix with the membrane in mature trichocysts (Adoutte, 1988), passage through the Golgi complex has been documented more clearly. A monoclonal AB, recognizing a 56/57-kDa component of the mesh-like sheath, also labels the Golgi complex (Momayezi et al., 1993). Finally, ABs against pretrichynins also produce Golgi labeling (Garreau De Loubresse, 1993). The same work, as well as that by Allen $\epsilon t$ al. (1989), shows some vesicles, budding off the Golgi complex which display a smooth cytoplasmic coat, probably of the coatamer type. Such Golgi vesicles do not bind ABs against mammalian COPs (which does not exclude such identity) and side-by-side bristle-coated vesicles are found (Allen and Fok, 1993b, 2000), probably for the transport of lysosomal enzymes. However, neither budding of COP nor of clathrin-coated vesicles has been analyzed in any detail in Paramecium as yet. Not only for a COP subunit, but also for the clathrin heavy chain, sequences are available from Paramecium (Table I) that should enable one for more detailed work.

In other eukaryotes, lysosomal enzymes may be delivered by clathrincoated vesicle budding from the TGN (Urbé et al., 1997; Avran and Castle, 1998). According to the ultrastructural details mentioned, one may assume the same for ciliates. In Tetrahymena, lysosomal enzymes analyzed so far are glycosylated (Taniguchi et al., 1985), although they lack a mannose-6-phosphate signal (Banno et al., 1993). (Note that not all mammalian lysosomal enzymes carry this tag.)

The occurrence of small G-proteins in Paramecium has been derived from Western overlay studies with radioactive GTP- $\gamma$-S (Peterson, 1991), but their contribution to any precise step of vesicle trafficking has not been sufficiently 
analyzed up to now. Table I summarizes preliminary partial cloning of different types of monomeric G-proteins in Paramecium. In addition to the work already published (Fraga and Hinrichsen, 1994), these authors have deposited additional sequences of a variety of monomeric G-proteins (Table I). This aspect would be particularly interesting regarding the interplay between G-proteins and SNAREs at membrane interaction sites, as "throttles and dampers" (Rothman and Söllner, 1997). The different Gproteins are understood as facilitating membrane interactions, while specificity may arise more from SNAREs (Avery et al., 1999; McNew et al., 2000; Scales et al., 2000; Xue and Zhang, 2002). For their function in vivo, they require auxiliary proteins of the type guanine nucleotide-activating proteins (GAP) and guanine nucleotide exchange factors (GEF), as they also emerge in the Paramecium genome (Table I).

How do Golgi-derived vesicles fuse to form the elaborate trichocyst structures (Adoutte, 1988; Garreau De Loubresse, 1993)? Considering the complex, polar structure of a trichocyst, with a "tip" and a "body" part, it would be interesting to know how the specific components of the secretory contents and the specific membrane components are put together, probably by specific vesicle fusion processes. This also occurs in higher eukaryotes (Tooze et al., 2001), where it depends on the $\mathrm{Ca}^{2+}$ sensor synaptotagmin (type III in mast cells; Grimberg et al., 2003), a gene product not known from Paramecium as yet. Some glycoproteins may be sorted out when trichocyst contents leave the Golgi complex (Allen et al., 1989). The matrix of the trichocyst body contains paracrystalline trichynin proteins derived from pretrichynins by proteolytic processing (Gautier et al., 1994, 1996). While some components are glycosylated (Glas-Albrecht et al., 1990), differential lectin-binding sites are concentrated in different domains within a trichocyst (Lüthe et al., 1986; Allen et al., 1988), the tip and contains secretory lectins (Haacke-Bell and Plattner, 1987). In total, these studies support a Golgi passage.

Normal trichocysts are not formed in the "trichless" mutant (Pollack, 1974) due to the absence of posttranslational cleavage of pretrichynins, which are then released in the untriggered mode (Gautier et al., 1994). This would be a good model for analyzing the cross-talk between contents and organelle surface with regard to the choice of the export route - the constitutive and the stimulated pathway, respectively (see Section IV,A). A normal trichocyst also contains an inherent polarity signal on its membrane surface, as it normally undergoes saltatory transport along microtubules, in plus $\rightarrow$ minus direction, with the tip first (Aufderheide, 1977; Plattner et al., 1982; Glas-Albrecht et al., 1991). In contrast, dense-core secretory vesicles ("chromaffin granules") isolated from bovine adrenal medullae, after injection into Paramecium cells, all accumulate at the plus end of microtubules, i.e., the direction they go in the cells of origin (Glas-Albrecht et al., 1990). Some mutants cannot deliver their trichocysts, often with aberrant ultrastructure, 
to the cell surface and in some other mutants the organellar polarity is disturbed, resulting in nonextrudable trichocysts at the cell membrane (Pouphile et al., 1986). Similar mutants defective on different levels of the secretory pathway have been obtained from Tetrahymena (Sauer and Kelly, 1995; Melia et al., 1998). With these cells it was also possible to show that secretory content sorting precedes condensation into a mature form (Turkewitz et al., 1991; Bowman and Turkewitz, 2001).

Another aspect of vesicle trafficking along the Golgi route is the delivery of vsAGs to the cell membrane, as we found in ultrathin section and freezefracture immuno gold-labeling studies (Flötenmeyer et al., 1999). After cloning NSF genes in Paramecium (Kissmehl et al., 2002) in our analysis of the ultrastructural effects of NSF gene silencing, we found circumstantial evidence of involvement of NSF-based molecular machinery on the ER and Golgi level. We found (i) inflated ER cisternae, as if products of ongoing synthetic activity could no longer be delivered further on, (ii) accumulation of small vesicles, labeled with ABs against NSF, amidst ER-rich domains, and (iii) fragmentation or even absence of Golgi areas (Kissmehl et al., 2002). In addition to NSF, another ATPase, p97, in conjunction with additional proteins, serves to establish contacts between internal membrane systems in higher eukaryotes (Uchiyama et al., 2002). No information on this is available from ciliates.

\section{Membrane Trafficking and Vesicle Movement}

\section{A. Exocytosis}

\section{Constitutive Exocytosis}

In Paramecium, this involves delivery of vsAGs to the cell membrane, probably at the same sites where parasomal sacs are formed during endocytosis (Capdeville et al., 1993; Flötenmeyer et al., 1999). The fact that these sites almost always display the coated pit/coated vesicle aspect, rather than showing delivery of smooth vesicles for constitutive exocytosis, may be explained easily by the longevity of the former, e.g., in metazoans (Marsh and McMahon, 1999; Sankaranarayanan and Ryan, 2000; Rappoport and Simon, 2003). NSF gene silencing (Kissmehl et al., 2002) resulted in a more or less aberrant ultrastructural appearance of these sites, as well as of the nearby early endosomes ("terminal cisternae"; see later).

Another constitutive exocytotic process is the release of pretrichynins by the "trichless" mutant, which cannot transform them by proteolytic cleavage to paracristalline assemblies (Garreau De Loubresse, 1993). This is also 
assumed for corresponding mutants in Tetrahymena (Bowman and Turkewitz, 2001). Also in Tetrahymena, an experimentally inhibited paracrystalline arrangement of mucocyst contents was found not to alter membrane trafficking (Chilcoat et al., 1996), as the organelles still find their preformed sites for stimulated exocytosis. The molecular determinants to divert stimulated from constitutive exocytosis have to be searched in the secretory organelle membrane components, not only in mammalian systems, but also in ciliates (Section IV,A,2). In mammalian cells, both pathways are deviated according to Kelly's "selection and exclusion" hypothesis for the delivery of secretory products into the stimulated and the constitutive pathway, respectively (Kelly, 1985; Urbé et al., 1997).

The ongoing release of lysosomal contents by constitutive exocytosis has been analyzed most thoroughly in Tetrahymena (Tiedtke et al., 1993). It appears to be $\mathrm{Ca}^{2+}$ dependent. The sites of release and the final function are under debate (Florin-Christensen et al., 1990). Remarkably, some enzymes, such as $\beta$-hexosaminidase, are released only partially into the medium, while they are retained partially on the cell surface (Kiy et al., 1993).

As in other systems, NSF-based processes may be involved not only in stimulated (Section IV,A,2), but also in constitutive exocytosis (Avran and Castle, 1998; Gerst, 1999). This has not yet been analyzed with ciliates and it has to remain open, therefore, for a variety of sites where constitutive exocytosis occurs in Paramecium. This concerns the two release sites of the contractile vacuoles and that of spent phagosomes ("cytoproct"). For the following reasons, they can be most safely assumed to use NSF and, therefore, by implication, also SNARE proteins. These sites are stained intensely by anti-NSF ABs when NSF detachment is inhibited by blocking its ATPase activity with ATP- $\gamma$-S (Kissmehl et al., 2002). From ciliates, no information is available on synaptotagmin involvement in lysosome trafficking, which is in contrast to mast cells, where it (negatively) modulates lysosome exocytosis (Baram et al., 1999). The cytoproct is also distinctly labeled by ABs against some common sequences of annexins (Knochel et al., 1996). These are ABs different from those that label trichocyst docking sites. This finding suggests the involvement of annexins in cytoproct positioning and/or functioning.

\section{Stimulated Exocytotic Pathway}

Trichocyst docking sites alternate with cilia along longitudinal rows (Allen, 1988). At the emergence of both these organelles, the layer of flat cortical calcium stores ("alveolar sacs"), which are tightly attached to the cell membrane, is interrupted. Within the cell membrane, trichocyst docking sites are delineated by a double row of freeze-fracture particles (proteins) arranged as a "parenthesis" before and as a 300-nm-wide "ring" after trichocyst docking, respectively (Plattner et al., 1993; Vayssié et al., 2000). Docking of 
a trichocyst normally entails the assembly of approximately nine "rosette" particles (proteins) in the center of a ring, i.e., directly in the fusogenic zone (Beisson et al., 1976; Pape and Plattner, 1990), as well as of "connecting material" between the two membranes (Beisson et al., 1980; Plattner et al., 1980). In most strains, the presence of a rosette is an infallible indication of exocytotic membrane fusion competence (Pouphile et al., 1986). In fact, a nondischarge mutant of $P$. caudatum, which unexpectedly possesses rosettes (Watanabe and Haga, 1996), was found to perform "silent" membrane fusion without any visible trichocyst release due to a mutated $\mathrm{Ca}^{2+}$-binding component in the secretory contents (Klauke et al., 1998). The only true exception known is strain $n d 12$, which, when cultivated at a nonpermissive temperature, possesses rosettes in the absence of any fusion capacity (Mohamed et al., 2002). Rosette assembly is also required for mucocyst secretion in Tetrahymena (Orias et al., 1983).

What is the molecular identity of trichocyst docking and fusion machinery, including connecting material, particularly rosette protein particles? In this context, a variety of sequences are available from Paramecium (Table I), notably for the following gene products: NSF, synapto-/cellubrevin, calmodulin $(\mathrm{CaM})$, monomeric G-proteins, and several ND gene products identified by rescue experiments and complementation cloning with nondischarge mutants (see later). Considering the many hours-long lifetime of a trichocyst docking site (Plattner et al., 1993), localization by anti-NSF ABs is not feasible because NSF is removed rapidly from adjacent membranes after establishing the SNARE interaction (Section II). Unfortunately, ABs against Paramecium SNAREs are also not available as yet. However, it could be shown that the assembly of rosettes, which may require only minutes (Pape and Plattner, 1990; Plattner et al., 1993; Klauke and Plattner, 2000), clearly requires SNAREs for the following reasons. In the $n d 9$ mutant, a $\sim 2$-h-long temperature shift from nonpermissive to permissive conditions $\left(28^{\circ} \mathrm{C} \rightarrow\right.$ $18^{\circ} \mathrm{C}$ ) normally causes the assembly of rosettes and induction of exocytosis capacity. NSF gene silencing applied during a $28^{\circ} \mathrm{C} \rightarrow 18^{\circ} \mathrm{C}$ transfer inhibits rosette assembly and functional recovery (Froissard et al., 2002).

Another component of trichocyst docking sites is the $\mathrm{Ca}^{2+}$-binding protein, CaM. We localized CaM by ABs against CaM from Paramecium precisely at docking sites (Momayezi et al., 1986), which is particularly concise in isolated cell surface complexes ("cortices"). Conversely, Kerboeuf et al. (1993) induced rosette assembly in a cam-mutant, containing mutated CaM, by transfection with the wild-type $\mathrm{CaM}$ gene. This was paralleled by acquirement of exocytosis competence. The role of $\mathrm{CaM}$ in establishing and/or maintaining trichocyst docking/exocytosis sites in a functional state is supported by the inhibitory effect of "anti-CaM drugs," which, in Paramecium, cause the detachment of trichocysts (Klauke and Plattner, 2000). CaM was found to participate in yeast vacuole fusion (Peters and 
Mayer, 1998) and in dense-core vesicle exocytosis in mammlians. In this context, CaM may account for a $\mathrm{Ca}^{2+}$-dependent priming of exocytosis, as it binds to a variety of components of the docking/fusion machinery, such as the v-SNARE, synaptobrevin (Quetglas et al., 2002), rab-type monomeric Gprotein (Coppola et al., 1999), and the putative $\mathrm{Ca}^{2+}$ sensor, synaptotagmin (Tucker and Chapman, 2002). Thus, $\mathrm{Ca}^{2+}$ not only mediates exocytotic membrane fusion, but it also primes docking sites (at a preceding stage; Von Rueden and Neher, 1993). Although synaptotagmin-the $\mathrm{Ca}^{2+}$ sensor to be expected also in ciliates-has so far remained undetected in Paramecium, we presume its occurrence based on a similar requirement of exocytotic membrane fusion for local $\mathrm{Ca}^{2+}$ increase (Plattner and Klauke, 2001). This is supported by acceleration of the exo endocytosis cycle by increasing the extracellular $\mathrm{Ca}^{2+}$ concentration (Plattner et al., 1997b), as it also occurs, for instance, in neuronal cells (Palfrey and Artalejo, 1998). Trichocyst exocytosis, which, just like in any other eukaryote, requires a $\mathrm{Ca}^{2+}$ signal (Erxleben et al., 1997; Plattner and Klauke, 2001), undoubtedly requires a $\mathrm{Ca}^{2+}$ sensor, but CaM is less likely to act as a sensor than synaptotagmin (Sugita et al., 2002). The actual $\mathrm{Ca}^{2+}$ sensor in ciliates definitely has to be identified.

Currently, we assume that the following components contribute to formation of the "connecting material" described previously: (i) CaM is one of the components; (ii) we conclude from indirect evidence obtained in our NSF studies that SNAREs are additional ones; (iii) furthermore, additional proteins, including monomeric G-proteins may contribute at least transiently; (iv) a synaptotagmin-like $\mathrm{Ca}^{2+}$ sensor appears mandatory; and (v) additional components are the ND7 (Skouri and Cohen, 1997) and ND9 gene products (Froissard et al., 2001) and possibly some proteins interacting with ABs against common sequences from mammalian annexins (Knochel et al., 1996).

In a scrutinized discussion on mechanisms of exocytotic membrane fusion in Paramecium (Plattner and Kissmehl, 2003), we tried to evaluate the potential relevance of two of the currently most discussed candidates for fusion pore formation: $V_{0}$ part of the $\mathrm{H}^{+}$-ATPase and SNAREs, respectively (Section II). For the availability of $V_{0}$ genes and the $a$ subunit, see Table I. Based on structural details of trichocyst exocytosis sites and their ultrastructural transformation during membrane fusion (Knoll et al., 1991), we found some arguments in favor of $V_{0}$, but unambiguous clarification again requires unequivocal identification by molecular biology. Conversely, is it mere coincidence that approximately nine rosette particles occur at an active trichocyst exocytosis site and that up to nine active fusion complexes in the sea urchin egg are calculated to be required for optimal operation of an exocytotic event (Vogel et al., 1996)? Meanwhile, molecular data on $\mathrm{H}^{+}$-ATPase components accumulate steadily and, in conjunction with ABs against its subunits and against SNAREs, may finally allow us to analyze their relevance for 
membrane fusion during trichocyst exocytosis. Consider that no decision has been reached so far in any other system where dense-core secretory organelle docking/fusion sites are structurally much less distinct.

\section{B. Endocytosis, Phagocytosis, and Lysosomal System}

\section{Endocytosis}

This is considered separate from phagocytosis (see Section IV,B,2) and we differentiate between exocytosis-coupled endocytosis and constitutive endocytosis via parasomal sacs. Considering the very detailed molecular informations on exo-endocytosis coupling in mammalian cells (Gundelfinger et al., 2003), amazingly little is known in Paramecium.

All work with Paramecium agrees that trichocyst "ghosts" are resealed, fragmented, and internalized without a clathrin coat (Allen and Fok, 1984; Plattner et al., 1985). According to quenched-flow/freeze-fracture analysis, all these steps are accelerated by an increasing extracellular $\mathrm{Ca}^{2+}$ concentration (Plattner et al., 1997a). Right after resealing, a "ring + rosette" configuration is transformed into a "filled ring" and then to a "parenthesis" (see Section IV,A,2) as ghosts detach (Knoll et al., 1991; Plattner et al., 1997b). Ghosts are removed completely, depending on the strain analyzed, normally with $t_{1 / 2} \sim 3$ to $9 \mathrm{~min}$ (Plattner et al., 1985). This step is also accelerated with an increasing extracellular $\mathrm{Ca}^{2+}$ concentration during stimulation (Plattner et al., 1997a), as it also occurs, for instance, in neurons (Palfrey and Artalejo, 1998) where it accelerates the internalization of SNAREs by endocytosis (Sankaranarayanan and Ryan, 2001). Trichocyst docking sites become available again for the insertion of new trichocysts, depending on organelle biogenesis, at a much slower rate (Plattner et al., 1993).

Vesicles arising from exocytosis-coupled endocytosis are of the smooth type (Plattner et al., 1985) and travel far into the cell, even close to the Golgi, complex as shown by peroxidase labeling (Allen and Fok, 1980, 1984), but recycling could not be shown. After a limited extent of exocytosis, the marker goes to secondary lysosomes (Allen and Fok, 1984). Massive exocytosis induction in the presence of a fluid phase marker entails delivery to digesting vacuoles (Lüthe et al., 1986).

Parasomal sacs are established sites of ongoing endocytosis in Paramecium and in Tetrahymena, as shown by the fluid phase marker horseradish peroxidase (Allen and Fok, 1993a; Allen et al., 1992) and by the application of cationic ferritin (Nilsson and VanDeurs, 1983), respectively. After endocytotic uptake, these markers reach flat compartments that have not been identified so far. Although parasomal sacs display a bristle coat, its identity 
with clathrin should now finally be shown because the gene of the heavy chain is now known (Table I). As to physiological functions of these sites, GPI-anchored vsAGs are pressed into these sites, probably by their mere abundance, and thus subjected to endocytosis and delivery to early endosomes (Allen et al., 1992; Allen and Fok, 1993; Fok and Allen, 1993), called "terminal cisternae," and food vacuoles, as derived from immunogold-labeling experiments with Paramecium (Flötenmeyer et al., 1999). This transport to digesting vacuoles may serve a permanent turnover (Capdeville et al., 1993).

In higher eukaryotes, coated vesicle formation requires an established set of proteins. Altogether, the molecular machinery required for endocytosis via coated pits is widely different from that for exocytosis. For the availability of gene sequences, see Table I. Depending on the type of endocytosis vesicle, this may include clathrin and its adaptor protein, AP2, dynamin, synaptojanin, and so on (Hinshaw, 2000; Sorkin, 2000), but not SNARE assemblies (Holroyd et al., 2002). There are different types of endocytosis vesicles and not all components are necessarily occurring at the same time, but dynamin is common to most of them (Conner and Schmid, 2003). In fact, dynamin does show up in Paramecium (AJ386320, AF351193, AL448655), in addition to the following indirect hints to its occurrence. Dynamin is dephosphorylated during endocytosis by the protein phosphatase 2B (PP2B, calcineurin, $\mathrm{CaN}$ ) (Marks and McMahon, 1998). PP2B has a catalytic CaMbinding $\mathrm{A}$ subunit and a $\mathrm{Ca}^{2+}$-binding regulatory $\mathrm{B}$ subunit (Klee $e t$ al., 1998). CaN has been isolated from Paramecium, and ABs prepared against it (Kissmehl et al., 1997) strongly labeled parasomal sacs on the EM level (Momayezi et al., 2000). Meanwhile, two genes of the A subunit has been cloned in the laboratory of R. D. Hinrichsen (AF 014922), and the B subunit has been cloned also in our laboratory (Table I). No other components are identified in Paramecium. This also holds for endosomes themselves.

Actin-binding proteins are also recruited to endocytosis sites (Marsh and McMahon, 1999; Qualman and Kessels, 2002). In a late stage of coated vesicle release from the cell membrane, F-actin assembly, between the plasma membrane and the pinched-off endocytotic vesicle, emerges in mammalian cells (Merrifield et al., 2002; Tse et al., 2003). Although F-actin occurs in the Paramecium cortex, its precise localization remains to be elucidated (see Section IV,B,2).

Membrane piecemeals from digesting vacuoles, after defecation, are retrieved from the cytoproct (Allen and Wolf, 1974; Allen and Fok, 1993a, 2000). Discoidal vesicles thus formed serve recycling to the nascent food vacuole. It is not understood whether labeling of the cytoproct by ABs against some common sequences of annexins (Knochel et al., 1996) is to be seen in connection with the exocytotic and/or with the endocytotic activities taking place at this site or merely in conjunction with positioning of the cytoproct. 
ABs against Paramecium NSF also label the cytoproct when the dissociation of NSF is inhibited (Kissmehl et al., 2002). This indicates the involvement of a SNARE machinery, probably in the exocytosis of the spent food vacuole.

\section{Phagocytosis and Lysosomal System}

Food bacteria are engulfed by ciliates at the cytopharynx, by formation of a nascent food vacuole that is acidified to kill the "prey," before the digesting (food) vacuole migrates by cyclosis through the cell. F-actin contributes to phagosome formation (see later) just as in mammalian cells (Zhang et al., 2002; Tse et al., 2003). Concerning Paramecium, we are ignorant about any involvement of rho-type monomeric G-proteins known in other cells (Chimini and Chavrier, 2000), but corresponding sequences are present (Table I). The subsequent pathway involves delivery and retrieval of lysosomal enzymes (Allen and Fok, 1993a, 2000; Fok and Allen, 1993).

In contrast to these scrutinized ultrastructural and functional analyses of the phagolysosomal cycle in Paramecium, molecular data are scant-in striking contrast to the wealth of information in mammalian cells (Chimini and Chavrier, 2000; Garin et al., 2001). We know nothing about the occurrence of the standard immuno marker for both, late endosomes and lysosomes, Lamp-2 (Clague, 1998), in ciliates. Again, although ABs against NSF also label the site of phagosome formation in Paramecium (Kissmehl et al., 2002), it is not known precisely which process it serves, i.e., phagosome fission, fusion with discoidal vesicles and/or acidosomes. From work with other cells, one may assume that only membrane fusions, but not fission processes, e.g., during phagosome formation, would require a NSF/SNAP/ SNARE machinery (Hinshaw, 2000; Sorkin, 2000). However, other work assumes that NSF would participate in phagosome formation (Coppolino et al., 2001), and phagosomal membranes isolated from mouse macrophages were found to contain such components (Garin et al., 2001). Any role of NSF in phagosome formation, if any, remains to be elucidated, but its occurrence may equally well reflect the multiple membrane-to-membrane interactions occurring in the life of a phagosome.

Before a nascent food vacuole is pinched off, two events take place: (i) F-actin is assembled (Allen and Fok, 1983; Kersken et al., 1986) and (ii) a number of acidosomes line up around the surface of a nascent food vacuole with which, after pinching off, they fuse rapidly (Allen and Fok, 1983). Acidosomes are small vesicles, so far of undetermined origin, that transport $\mathrm{H}^{+}$-ATPase molecules to nascent phagosomes. For sequences available, see Table 1. Whether an equivalent pathway also occurs in mammalian cells is not ascertained. Also, the signal for the rapid, multiple fusion of acidosomes with a food vacuole remains to be elucidated. Also unknown is the involvement, along the digestive cycle, of $V_{0}$ subunits of the $\mathrm{H}^{+}$-ATPase 
in the respective fusion processes. If $V_{0}$ subunits would ever act as a fusogen, this would most likely occur here, where it abounds so much (Fok et al., 2002), particularly as this function has been derived from analyses with yeast vacuoles (Section II). The binding of $\mathrm{CaM}$ to phagosomal membranes along their pathway (Momayezi et al., 1986) suggests a role in membrane interaction, as it is required for such interaction and final fusion in yeast vacuoles (Peters and Mayer, 1998). Accordingly, CaM and $\mathrm{Ca}^{2+} / \mathrm{CaM}$-binding proteins are encountered on the surface of phagocytic vacuoles of $T$. thermophila (Gonda et al., 2000).

As outlined in Section IV,A,1, materials ingested by smooth vesicles formed during exocytosis-coupled endocytosis, as well as by coated vesicles, can also be delivered to the phagolysosomal system. In this case, a signal indicating the "empty" state has to mediate this transport route. This is opposite to the findings during "frustrated exocytosis," where a signal indicating the "filled" state allows the reattachment of trichocysts previously detached without preceding contents release (Section IV,C,1).

NSF gene-silencing experiments have resulted in the inhibition of phagocytotic vacuole formation, decreasing cell size, and finally in cell death (Froissard et al., 2002; Kissmehl et al., 2002). Immunofluorescence labeling by anti-NSF ABs was visible most clearly at the beginning and at the end of the digestive cycle, i.e., at the cytopharynx and the cytoproct, respectively. However, at the EM level, the increased delivery of NSF into bona fide lysosomes was recognized (Kissmehl et al., 2002). It is difficult to judge whether this simply indicates the disposal of aged NSF molecules in the absence of any further biosynthesis.

Further aspects of membrane trafficking along the phagosomal route, to be elucidated on a molecular scale, are the fusion with lysosomes and the retrieval of lysosomal enzymes at a later stage (Allen and Fok, 1993a, 2000; Fok and Allen, 1993). Ciliates offer the advantage of precise timing of the phagocytic cycle, i.e., one can isolate defined phagosomal stages, as established for Tetrahymena (Vosskühler and Tiedtke, 1993). In Tetrahymena, some of the spots of two-dimensional electrophoresis gels have been partially microsequenced (Maicher and Tiedtke, 1999) - two of them were novel. Along the phagocytic pathway of $T$. thermophila different monomeric G-proteins are attached sequentially (Meyer et al., 1998). This may reflect selective vesicle interaction steps.

Very strikingly, NSF gene silencing increased the number of autophagosomes considerably (Kissmehl et al., 2002), although their formation begins with closure of a wrapping membrane compartment (ER), i.e., by a membrane fusion process. Our data are compatible with findings in Saccharomyces cerevisiae (Ishihara et al., 2001), where this step does not require NSF/ SNARE machinery, in contrast to fusion of autophagosomes with the vacuole (lysosome). Inhibition of this NSF-dependent step may be one reason of 
the accumulation of autophagosomes in Paramecium after NSF gene silencing. The primary reason may be their increased formation due to starvation, as NSF gene silencing shuts down food delivery via phagocytosis (Froissard et al., 2002). Accordingly, in Tetrahymena, starvation induces autophagy (Nillson and VanDeurs, 1983).

To summarize, with none of the manifold membrane interactions occurring during the digestive cycle is the molecular basis of membrane interaction and fusion known in any satisfactory detail. However, one may reasonably assume the following details. (i) F-actin, which coats nascent and later food vacuoles (Allen and Fok, 1983; Kersken et al., 1986), may participate in or even mediate cyclosis, and it would have to be organized in a loose form to allow organelle interactions. F-actin contributes to phagosome formation, just like in mammalian cells (Zhang et al., 2002; Tse et al., 2003). (ii) CaM and a NSF-based machinery are probably involved in these membrane interactions. (iii) Apart form SNAREs, $V_{0}$ would be available as a candidate for fusion pore formation.

F-actin is generally assumed to be required to drive cyclosis, also in Paramecium (Sikora, 1981). Several actin genes have been cloned in Paramecium by Díaz-Ramos et al. (1998) and in our laboratory. Data available previously have been corrected and supplemented by additional sequences (R. Kissmehl, E. Wagner, J. Mansfeld, and H. Plattner, unpublished observations). The localization and function of the respective gene products have not yet been completed.

\section{Long-Range Vesicle Movements}

\section{Detachment of Mature Trichocysts from the Cell Surface}

The application of "anti-CaM drugs" or of increased $\mathrm{Mg}^{2+}$ concentrations in the medium can detach exocytosis-competent trichocysts from the cell membrane (Klauke and Plattner, 2000). The requirement of CaM for establishing trichocyst docking sites has been commented in Section IV,A,2. It is not known whether the enrichment of $\mathrm{CaN}$ at and close to docking sites (Momayezi et al., 2000) is relevant directly for exocytosis or exocytosiscoupled endocytosis or indirectly, e.g., for governing $\mathrm{Ca}^{2+}$ dynamics. Experimentally detached trichocysts (still containing their secretory contents) can be reinserted and undergo stimulated exocytosis. From this we conclude that (i) trichocysts dispose of a "filled" signal and (ii) that CaM is involved in docking (see also Section IV,A,2). No comparable information is available from any other eukaryotes.

In Paramecium, as in mammals, an "empty-or-filled" signal may be represented by transmembrane proteins with a lumenal link to the secretory 
contents. On a speculative basis, in Paramecium, such a link could be represented by a component of the "mesh-like sheath," notably by a $56-\mathrm{kDa}$ protein (Momayezi et al., 1993) (see Section IV,A,2). One could speculate whether the GP-2 protein in pancreatic zymogen granules could serve a similar function (Kalus et al., 2002). In both these cases, the existence of an "empty/filled" signal and its involvement in directed transport would require much more scrutinized analysis.

\section{Microtubules as Long-Range Signals for Vesicle Trafficking}

A Paramecium cell has a variety of distinct arrays of microtubules (Cohen and Beisson, 1988), among which some are displayed along distinct vesicle transport routes. Microtubules emanate from the cytoproct (Allen and Wolf, 1974) where they may serve the docking of a spent food vacuole. Another population of microtubular "rails" is installed between the cytoproct and the cytopharynx for discoidal vesicle transport (Allen and Fok, 1980). Microtubules also flank the radial canals of the osmoregulatory system (Allen, 2000; Allen and Naitoh, 2002), which they may stabilize. Finally, a much less obvious population originates from ciliary basal bodies in a vertical direction from the cell surface and mediates saltatory docking of trichocysts (Plattner et al., 1982; Glas-Albrecht et al., 1991). The $\gamma$-tubulin, associated with ciliary basal bodies (Ruiz et al., 1999), is required to establish basal bodies as microtubule-organizing centers. Microtubules do not participate in membrane transport in the opposite direction, i.e., exocytosis-coupled endocytosis (Plattner et al., 1985).

For versicle trafficking in Paramecium, cytoplasmic dynein is the only motor protein that has been functionally characterized up until now (Schroeder et al., 1990). Due to its preference for " $+\rightarrow-$ " transport, it may be involved in trichocyst docking. Remarkably, such " $+\rightarrow-$ " directed transport to the cell periphery, as established for trichocysts (Plattner et al., 1982; Glas-Albrecht et al., 1991), has also been found in epithelia (Bacallao et al., 1989; Bré et al., 1990).

\section{Results Relevant to Membrane Trafficking in Paramecium}

Table I summarizes the relevant molecular details known so far from Paramecium. Many sequences available are fragmentary and, thus, require confirmation and further specification by additional work. With partial sequences it cannot be excluded that they are domains occurring in different proteins. So far it appears that Paramecium, on an early stage of evolution, is using, in principle, the same molecular elements as "higher" eukaryotic systems. 
Originally, data have been derived from the analysis of the respective proteins. Complementation cloning, with identification of the respective gene and gene product, was another approach (Haynes et al., 1996) that proved highly rewarding in the analysis of membrane trafficking (Skouri and Cohen, 1997; Vayssié et al., 2000; Froissard et al., 2001). In the last few years, the international Paramecium genome project (Dessen et al., 2001) has provided important input. This is currently pursued on a European scale as a GDRE project (Groupement de Recherche Européen), headed and administered by Jean Cohen and Linda Sperling (CNRS, Gif-sur-Yvette; France). An internet connection is available at http://paramecium.cgm. cnrs-gif.fr.

With most genes analyzed so far in Paramecium, more than one, frequently several, isoforms are found. They are frequently similar to each other, thus facilitating the silencing of different genes in the course of a single gene (ORF) injection (Ruiz et al., 1998; Bastin et al., 2001). It remains to be seen whether this is an alternative to alternative splicing, whether all gene variations are expressed, and whether the corresponding gene products are differentially positioned in the cell. Rapid progress of the Tetrahymena genome project (Turkewitz et al., 2002) will be an additional potential source for unraveling molecular details pertinent to membrane trafficking in ciliated protozoa.

\section{Conclusions and Perspectives}

A vast body of cell-biological work with Paramecium provides a solid baseline, which, together with rapid progress in molecular biology, will maintain the status of this organism as an important model system. One of the main questions to solve will be: How is the regular arrangement of the diverse membrane trafficking pathways determined?

In the past, specifically in Paramecium, complementation cloning proved useful to identify relevant genes and the function of the respective gene products (Sections II,B and IV,D). Microinjection of appropriate constructs into the macronucleus allows us to obtain transfected clones (Vayssié et al., 2000). This includes the overexpression of GFP-fusion proteins (Hauser et al., 2000a,b). It is hoped that electroporation or "bioballistic" methods (bombardment with DNA-coated gold particles) will allow us to achieve stable transfectants (Boileau et al., 1999). Homology-dependent gene silencing by injection of a large number of ORFs, without flanking regions (Ruiz et al., 1998; Bastin et al., 2001; Galvani and Sperling, 2001), has already proved useful in analyzing some aspects of membrane trafficking in Paramecium (Froissard et al., 2001; Kissmehl et al., 2002). Its effect is not fully 
understood, but basically it may be due to the binding of complementary nucleotide sequences (Wassengger, 2002). Recent methodological developments may render gene silencing more easily applicable by feeding of transfected bacteria (Galvani and Sperling, 2002). In Tetrahymena, "antisense ribosome" systems have been established (Turkewitz et al., 2002). This involves vectors with an antisense $5^{\prime}$ part inserted into ribosomes.

Because membrane traffic can be studied only in the structural context of a cell, the highly regular pattern of a Paramecium cell will keep this organism as a focus of interest. This is a realistic goal, particularly as it becomes increasingly amenable to molecular biology.

\section{Note added in proof:}

To Section I. The most detailed account available of the Paramecium genome project (Sperling et al., 2002, Eukaryot. Cell 1, 341-352) will soon be supplemented by additional sequences. Any new informations can be drawn from the internet address of the colleagues guiding this and the GDRE project, J. Cohen and L. Sperling (http://paramecium.cgm.cnrsgif.fr).

To Section III. Meanwhile sequences encoding parts of synaptotagmin gene(s) have been identified in our laboratory.

To Section $I V, B, 1$. For partial sequences of dynamin 2 and rab 7 in Paramecium, see Surmacz et al., 2003, Biol. Cell 95, 69-74.

To Section $I V, B, 2$. Synaptotagmin has been reported to participate also in internal fusion processess, like formation of some endosomal compartments (Grimberg et al., 2003, J. Cell Sci. 116, 145-154.)

\section{Acknowledgments}

We thank all our co-workers and cooperation partners for their invaluable contributions integrated in this review, and specifically Dr. J. Hentschel for elaborating the scheme. We gratefully acknowledge the financial support of the authors work cited herein by the Deutsche Forschungsgemeinschaft.

\section{References}

Adoutte, A. (1988). Exocytosis: Biogenesis, transport and secretion of trichocysts. In "Paramecium" (H. D. Görtz, Ed.), pp. 325-362. Springer-Verlag, Berlin.

Allen, R. D. (2000). The contractile vacuole and its membrane dynamics. BioEssays 22, $1035-1042$.

Allen, R. D. (1988). Cytology. In "Paramecium"(H. D. Görtz, Ed.), pp. 4-40. Springer-Verlag, Berlin.

Allen, R. D., and Fok, A. K. (1980). Membrane recycling and endocytosis in Paramecium confirmed by horseradish peroxidase pulse-chase studies. J. Cell Sci. 45, 131-145. 
Allen, R. D., and Fok, A. K. (1983). Nonlysosomal vesicles (acidosomes) are involved in phagosome acidification in Paramecium. J. Cell Biol. 97, 566-570.

Allen, R. D., and Fok, A. K. (1984). Membrane behavior of exocytic vesicles. III. Flow of horseradish peroxidase labeled trichocyst membrane remnants in Paramecium. Eur. J. Cell Biol. 35, 27-34.

Allen, R. D., and Fok, A. K. (1993a). Endosomal membrane traffic of ciliates. In "Membrane Traffic in Protozoa” (H. Plattner, Ed.), pp. 283-309. JAI Press, Greenwich, CT.

Allen, R. D., and Fok, A. K. (1993b). Nonclathrin vesicle coats and filament networks in the transition zone and trans-Golgi region of the Golgi complex of Paramecium. J. Struct. Biol. 110, 215-226.

Allen, R. D., and Fok, A. K. (2000). Membrane trafficking and processing in Paramecium. Int. Rev. Cytol. 198, 277-317.

Allen, R. D., and Naitoh, Y. (2002). Osmoregulation and contractile vacuoles of protozoa. Int. Rev. Cytol. 215, 351-394.

Allen, R. D., and Wolf, R. W. (1974). The cytoproct of Paramecium caudatum: Structure and function, microtubules, and fate of food vacuole membranes. $J$. Cell Sci. 14, 611-631.

Allen, R. D., Schroeder, C. C., and Fok, A. K. (1992). Endosomal system of Paramecium: Coated pits to early endosomes. J. Cell Sci. 101, 449-461.

Allen, R. D., Schroeder, C. C., and Fok, A. K. (1989). Intracellular binding of wheat germ agglutinin by Golgi complexes, phagosomes and lysososmes in Paramecium multimicronucleatum. J. Histochem. Cytochem. 37, 195-202.

Allen, R. D., Ueno, M. S., and Fok, A. K. (1988). A survey of lectin binding in Paramecium. $J$. Protozool. 35, 400-407.

Aufderheide, K. J. (1977). Saltatory motility of uninserted trichocysts and mitochondria in Paramecium tetraurelia. Science 198, 299-300.

Avery, J., Jahn, R., and Edwardson, J. M. (1999). Reconstitution of regulated exocytosis in cellfree systems: A critical appraisal. Annu. Rev. Physiol. 61, 777-807.

Avran, P., and Castle. D. (1998). Sorting and storage during secretory granule biogenesis: Looking backward and looking forward. Biochem. J. 332, 593-610.

Bacallao, R., Antony, C., Dotti, C., Karsenti, E., Stelzer, E. H. K., and Simons, K. (1989). The subcellular organization of Madin-Darby canine kidney cells during the formation of a polarized epithelium. J. Cell Biol. 109, 2817-2832.

Banno, Y., Okano, Y., Furukawa, K., Tiedtke, A., Kobata, A., and Nozawa, Y. (1993). Processing and secretion of lysosomal acid $\alpha$-glucosidase in Tetrahymena wild type and secretion-deficient mutant cells. J. Eukaryot. Microbiol. 40, 515-520.

Baram. D., Adachi, R., Medalia, O., Tuvirn, M., Dickey, B., Makori, Y., and Sagi-Eisenberg, R. (1999). Synaptotagmin II negatively regulates $\mathrm{Ca}^{2+}$-triggered exocytosis of lysosomes in mast cells. J. Exp. Med. 189, 1649-1658.

Bastin, P., Galvani, A., and Sperling, L. (2001). Genetic interference in protozoa. Res. Microbiol. 152, 123-129.

Beisson, J., Cohen, J., Lefort-Tran, M., Pouphile, M., and Rossignol, M. (1980). Control of membrane fusion in exocytosis: Physiological studies on a Paramecium mutant blocked in the final step of the trichocyst extrusion process. J. Cell Biol. 85, 213-227.

Beisson, J., Lefort-Tran, M., Pouphile, M., Rossignol, M., and Satir, B. (1976). Genetic analysis of membrane differentiation in Paramecium: Freeze-fracture study of the trichocyst cycle in wild-type and mutant strains. J. Cell Biol. 69, 126-143.

Boileau, A. J., Kissmehl, R., Kanabrocki, J. A., and Saimi, Y. (1999). Transformation of Paramecium tetraurelia by electroporation or particle bombardement. J. Eukaryot. Microbiol. 46, 56-65.

Bowman, G. R., and Turkewitz, A. P. (2001). Analysis of a mutant exhibiting conditional sorting to dense core secretory granules in Tetrahymena thermophila. Genetics 159, 1605-1616. 
Brand, S. H., and Castle, J. C. (1993). SCAMP 37, a new marker within the general cell surface recycling system. EMBO J. 12, 3753-3761.

Bré, M. H., Pepperkok, R., Hill, A. M., Levilliers, N., Ansorge, W., Stelzer, E. H. K., and Karsenti, E. (1990). Regulation of microtubule dynamics and nucleation during polarization in MDCK II cells. J. Cell Biol. 111, 3013-3021.

Capdeville, Y. (2000). Paramecium GPI proteins: Variability of expression and localization. Protist 151, 161-169.

Capdeville, Y., Charret, R., Antony, C., Delorme, J., Nahon, P., and Adoutte, A. (1993). Ciliary and plasma membrane proteins in Paramecium: Description, localization, and intracellular transit. In "Membrane Traffic in Protozoa" (H. Plattner, Ed.), pp. 181-226. JAI Press, Greenwich, CT.

Chamberlain, L. H., Burgoyne, R. D., and Gould, G. W. (2001). SNARE proteins are highly enriched in lipid rafts in PC12 cells: Implications for the spatial control of exocytosis. Proc. Natl. Acad. Sci. USA 98, 5619-5624.

Chilcoat, N. D., Melia, S. M., Haddad, A., and Turkewitz, A. P. (1996). Granule lattice protein 1 (Grllp), an acidic, calcium-binding protein in Tetrahymena thermophila dense core secretory granules, influences granule size, shape, content organization, and release but not protein sorting or condensation. J. Cell Biol. 135, 1775-1787.

Chimini, G., and Chavrier, P. (2000). Function of Rho family proteins in actin dynamics during phagocytosis and engulfment. Nature Cell Biol. 2, E191-E196.

Clague, M. J. (1998). Molecular aspects of the endocytic pathway. Biochem. J. 336, 271-282.

Cohen, J., and Beisson, J. (1988). The cytoskeleton. In "Paramecium" (H. D. Görtz, Ed.), pp. 363-392. Springer-Verlag, Berlin.

Conner, S. D., and Schmid, S. L. (2003). Regulated protals of entry into the cell. Nature 422, $37-44$.

Coppola, T., Perret-Manoud, V., Lüthi, S., Farnsworth, C. C., Glomset, J. A., and Regazzi, R. (1999). Distruption of Rab3-calmodulin interaction, but not other effector interactions, prevents Rab3 inhibition of exocytosis. EMBO J. 18, 5885-5891.

Coppolino, M. G., Kong, C., Mohtashami, M., Schreiber, A. D., Brumell, J. H., Finlay, B. B., Grinstein, S., and Trimble, W. S. (2001). Requirement for N-ethylmaleimide-sensitive factor activity at different stages of bacterial invasion and phagocytosis. J. Biol. Chem. 276, 4772-4780.

Dessen, P., Zagulski, M., Gromadka, R., Plattner, H., Kissmehl, R., Meyer, E., Bétermier, M., Schultz, J. E., Linder, J. U., Pearlman, R. E., Kung, C., Forney, J., Satir, B. H., Van Houten, J. L., Keller, A. M., Froissard, M., Sperling, L., and Cohen, J. (2001). Paramecium genome survey: A pilot project. Trends Genet. 17, 306-308.

Díaz-Ramos, C., Villalobo, E., Pérez-Romero, P., and Torres, A. (1998). Paramecium tetraurelia encodes unconventional actin containing short introns. J. Eukaryot. Microbiol. 45, 507-511.

Erxleben, C., Klauke, N., Flötenmeyer, M., Blanchard, M. P., Braun, C., and Plattner, H. (1997). Microdomain $\mathrm{Ca}^{2+}$ activation during exocytosis in Paramecium cells: Superposition of local subplasmalemmal calcium store activation by local $\mathrm{Ca}^{2+}$ influx. J. Cell Biol. 136, 597-607.

Estève, J. C. (1972). L'appareil de Golgi des ciliés. Ultrastructure, particulièrement chez Paramecium. J. Protozool. 19, 609-618.

Ferguson, M. A. J. (1999). The structure, biosynthesis and functions of glycosylphosphatidylinositol anchors, and the contributions of trypanosome research. J. Cell Sci. 112, 2799-2809.

Florin-Christensen, J., Florin-Christensen, M., Rasmussen, L., and Tiedtke, A. (1990). Release of lysosomal enzymes in Tetrahymena: A calcium-dependent event. In "Calcium as an Intracellular Messenger in Eukaryotic Microbes” (D. H. O'Day, Ed.), pp. 151-164. Am. Soc. Microbiol, Washington, DC. 
Flötenmeyer, M., Momayezi, M., and Plattner, H. (1999). Immunolabeling analysis of biosynthetic and degradative pathways of cell surface components (glycocalyx) in Paramecium cells. Eur. J. Cell Biol. 78, 67-77.

Fok, A. K., and Allen, R. D. (1993). Membrane flow in the digestive cycle of Paramecium. In "Membrane Traffic in Protozoa" (H. Plattner, Ed.), pp. 311-337. JAI Press, Greenwich, CT.

Fok, A. K., Yamauchi, K., Ishihara, A., Aihara, M. S., Ishida, M., and Allen, R. D. (2002). The vacuolar-ATPase of Paramecium multimicronucleatum gene structure of the B subunit and the dynamics of the V-ATPase-rich osmoregulatory membranes. J. Eukaryot. Microbiol. 49, $185-196$.

Fraga, D., and Hinrichsen, R. D. (1994). The identification of a complex family of lowmolecular weight GTP-binding protein homologues from Paramecium tetraurelia by PCR cloning. Gene 147, 145-148.

Froissard, M., Keller, A. M., and Cohen, J. (2001). ND9P, a novel protein with armadillo-like repeats involved in exocytosis: Physiological studies using allelic mutants in Paramecium. Genetics 157, 611-620.

Froissard, M., Kissmehl, R., Dedieu, J. C., Gulik-Krzywicki, T., Plattner, H., and Cohen, J. (2002). N-ethylmaleimide-sensitive factor is required to organize functional exocytotic microdomains in Paramecium. Genetics 161, 643-650.

Galvani, A., and Sperling, L. (2002). RNA interference by feeding in Paramecium. Trends Genet. 18, 11-12.

Galvani, A., and Sperling, L. (2001). Transgene-mediated post-transcriptional gene silencing is inhibited by $3^{\prime}$ non-coding sequences in Paramecium. Nucleic Ac. Res. 29, 4387-4394.

Garin, J., Diez, R., Kieffer, S., Dermine, J.-F., Duclos, S., Gagnon, E., Sadoul, R., Rondeau, C., and Desjardins, M. (2001). The phagosome proteome: Insight into phagosome functions. J. Cell Biol. 152, 165-180.

Garreau De Loubresse, N. (1993). Early steps of the secretory pathway in Paramecium: Ultrastructural immunocytochemical and genetic analysis of trichocyst biogenesis. In "Membrane Traffic in Protozoa" (H. Plattner, Ed.), pp. 27-59. JAI Press, Greenwich, CT.

Gautier, M. C., Garreau de Loubresse, N., Madeddu, L., and Sperling, L. (1994). Evidence for defects in membrane traffic in Paramecium secretory mutants unable to produce functional storage granules. J. Cell Biol. 124, 893-902.

Gautier, M. C., Sperling, L., and Madeddu. L. (1996). Cloning and sequence analysis of genes coding for Paramecium secretory granule (trichocyst) proteins: A unique protein fold for a family of polypeptides with different primary structures. $J$. Biol. Chem. 271, 10247-10255.

Gerst, J. E. (1999). SNAREs and SNARE regulators in membrane fusion and exocytosis. Cell. Mol. Life Sci. 55, 707-734.

Glas-Albrecht, R., Kaesberg, B., Knoll, G., Allmann, K., Pape, R., and Plattner, H. (1991). Synchronised secretory organelle docking in Paramecium: Saltatory movement along microtubules transiently formed from ciliary basal bodies and selective exclusion of microinjected heterologous organelles. J. Cell Sci. 100, 45-54.

Glas-Albrecht, R., Németh, A., and Plattner, H. (1990). Secretory proteins and glycoproteins from Paramecium cells. Eur. J. Protistol. 26, 149-159.

Gonda, K., Komatsu, M., and Numata, O. (2000). Calmodulin and $\mathrm{Ca}^{2+} /$ calmodulin-binding proteins are involved in Tetrahymena thermophila phagocytosis. Cell Struct. Funct. 25, 243-251.

Görtz, H. D. (1988). "Paramecium." Springer-Verlag, Berlin.

Grimberg, E., Peng, Z., Hammel, I., and Sagi-Eisenberg, R. (2003). Synaptotagmin III is a critical factor for the formation of the perinuclear endocytic recycling compartment and determination of secretory granule size. J. Cell Sci. 116, 145-154.

Gundelfinger, E. D., Kessels, M. M., and Qualmann, B. (2003). Temporal and spatial coordination of exocytosis and endocytosis. Nature Rev. Mol. Cell Biol. 4, 127-139. 
Haacke-Bell, B., and Plattner, H. (1987). Secretory lectins contained in trichocyst tips of Paramecium. Eur. J. Cell Biol. 44, 1-9.

Hauser, K., Haynes, W. J., Kung, C., Plattner, H., and Kissmehl, R. (2000). Expression of the green fluorescent protein in Paramecium tetraurelia. Eur. J. Cell Biol. 79, 144-149.

Hauser, K., Pavlovic, N., Klauke, N., Geissinger, D., and Plattner, H. (2000). Green fluorescent protein-tagged sarco(endo)plasmic reticulum $\mathrm{Ca}^{2+}$-ATPase overexpression in Paramecium cells: Isoforms, subcellular localization, biogenesis of cortical calcium stores and functional aspects. Mol. Microbiol. 37, 773-787.

Haynes, W. J., Ling, K. Y., Saimi, Y., and Kung, C. (1996). Toward cloning genes by complementation in Paramecium. J. Neurogenet. 11, 81-98.

Hinners. I., and Tooze, S. A. (2003). Changing directions: Clathrin-mediated transport between the Golgi and endosomes. J. Cell Sci. 116, 763-771.

Hinshaw, J. E. (2000). Dynamin and its role in membrane fission. Annu. Rev. Cell Dev. Biol. 16, 483-519.

Holroyd, P., Lang, T., Wenzel, D., DeCamilli, P., and Jahn, R. (2002). Imaging direct, dynamin-dependent recapture of fusing secretory granules on plasma membrane lawns from PC12 cells. Proc. Natl. Acad. Sci. USA 99, 16806-16811.

Ishihara, N., Hamasaki, M., Yokota, S., Suzuki, K., Kamada, Y., Kihara, A., Yoshimori, T., Noda, T., and Ohsumi, Y. (2001). Autophagosome requires specific early Sec proteins for its formation and NSF/SNARE for vacuolar fusion. Mol. Biol. Cell 12, 3690-3702.

Jahn, R., and Grubmüller, H. (2002). Membrane fusion. Curr. Opin. Cell Biol. 14, 488-495.

Jahn, R., and Südhof, T. C. (1999). Membrane fusion and exocytosis. Annu. Rev. Biochem. 68, 863-911.

Kalus, I., Hodel, A., Koch, A., Kleene, R., Edwardson, J. M., and Schrader, M. (2002). Interaction of syncollin with GP-2, the major membrane protein of pancreatic zymogen granules, and association with lipid microdomains. Biochem. J. 362, 433-442.

Keller, A. M., and Cohen, J. (2000). An indexed genomic library for Paramecium complementation cloning. J. Eukaryot. Microbiol. 47, 1-6.

Kelly, R. B. (1985). Pathways of protein secretion in eukaryotes. Science 230, 25-32.

Kerboeuf, D., Leberre, A., Dedieu, J. C., and Cohen, J. (1993). Calmodulin is essential for assembling links necessary for exocytotic membrane fusion in Paramecium. EMBO J. 12, 3385-3390.

Kersken, H., Vilmart-Seuwen, J., Momayezi, M., and Plattner, H. (1986). Filamentous actin in Paramecium cells: Mapping by phalloidin affinity labeling in vivo and in vitro. $J$. Histochem. Cytochem. 34, 443-454.

Kirchhausen, T. (2000). Three ways to make a vesicle. Nature Rev. Mol. Cell Biol. 1, 187-198.

Kissmehl, R., Froissard, M., Plattner, H., Momayezi, M., and Cohen, J. (2002). NSF regulates membrane traffic along multiple pathways in Paramecium. J. Cell Sci. 115, 3935-3946.

Kissmehl, R., Treptau, T., Kottwitz, B., and Plattner, H. (1997). Occurrence of a paranitrophenyl phosphate-phosphatase with calcineurin-like characteristics in Paramecium tetraurelia. Arch. Biochem. Biophys. 344, 260-270.

Kiy, T., Vosskühler, C., Rasmussen, L., and Tiedtke, A. (1993). Three pools of lysosomal enzymes in Tetrahymena thermophila. Exp. Cell Res. 205, 286-292.

Klauke, N., Kissmehl, R., Plattner, H., Haga, N., and Watanabe, T. (1998). An exocytotic mutant of Paramecium caudatum: Membrane fusion without secretory contents release. Cell Calcium 23, 349-360.

Klauke, N., and Plattner, H. (2000). Frustrated exocytosis - a novel phenomenon: Membrane fusion without contents release, followed by detachment and reattachment of dense core vesicles in Paramecium cells. J. Membr. Biol. 176, 237-248.

Klee, C. B., Ren, H., and Wang, X. (1998). Regulation of the calmodulin-stimulated protein phosphatase, calcineurin. J. Biol. Chem. 273, 13367-13370. 
Knochel, M., Kissmehl, R., Wissmann, J. D., Momayezi, M., Hentschel, J., Plattner, H., and Burgoyne, R. (1996). Annexins in Paramecium cells: Involvement in site-specific positioning of secretory organelles. Histochem. Cell Biol. 105, 269-281.

Knoll, G., Braun, C., and Plattner, H. (1991). Quenched flow analysis of exocytosis in Paramecium cells: Time course, changes in membrane structure, and calcium requirements revealed after rapid mixing and rapid freezing of intact cells. J. Cell Biol. 113, 1295-1304.

Kung, C., Saimi, Y., Haynes, W. J., Ling, K. Y., and Kissmehl, R. (2000). Recent advances in the molecular genetics of Paramecium. J. Eukaryot. Microbiol. 47, 11-14.

Kurz, S., and Tiedtke, A. (1993). The Golgi apparatus of Tetrahymena thermophila. J. Eukaryot. Microbiol. 40, 10-13.

Lang, T., Bruns, D., Wenzel, D., Riedel, D., Holroyd, P., Thiele, C., and Jahn, R. (2001). SNAREs are concentrated in cholesterol-dependent clusters that define docking and fusion sites for exocytosis. EMBO J. 20, 2202-2213.

Leach, M. R., Cohen-Doyle, M. F., Thomas, D. Y., and Williams, D. B. (2002). Localization of the lectin, ERp57, and polypeptide binding sites of calnexin and calreticulin. J. Biol. Chem. 277, 29686-29697.

Littleton, J. T., Barnard, R. O., Titus, S. A., Slind, J., Chapman, E. R., and Ganetzky, B. (2001). SNARE-complex disassembly by NSF follows synaptic-vesicle fusion. Proc. Natl. Acad. Sci. USA 98, 12233-12238.

Liu, L., Guo, Z., Tieu, Q., Castle, A., and Castle, D. (2002). Role of secretory carrier membrane protein SCAMP2 in granule exocytosis. Mol. Biol. Cell 13, 42664278.

Lüthe, N., Plattner, H., Haacke, B., Walther, W., and Müller, M. (1986). Lectin binding sites in Paramecium tetraurelia cells. I. Labeling analysis predominantly of secretory components. Histochemistry 85, 365-376.

Maicher, M. T., and Tiedtke, A. (1999). Biochemical analysis of membrane proteins from an early maturation stage of phagosomes. Electrophoresis 20, 1011-1016.

Malkus, P., Jiang, F., and Schekman, R. (2002). Concentrative sorting of secretory cargo proteins into COPII-coated vesicles. J. Cell Biol. 159, 915-921.

Marks, B., and McMahon, H. T. (1998). Calcium triggers calcineurin-dependent synaptic vesicle recycling in mammalian nerve terminals. Curr. Biol. 8, 740-749.

Marsh, M., and McMahon, H. T. (1999). The structural era of endocytosis. Science 285, 215-220.

Martin, T. F. J. (2002). Prime movers of synaptic vesicle exocytosis. Neuron 34, 9-12.

Mayer, A. (2002). Membrane fusion in eukaryotic cells. Annu. Rev. Cell Dev. Biol. 18, 289-314.

Mayer, A. (2001). What drives membrane fusion in eukaryotes? Trends Biochem. Sci. 26, 717-723.

McNew, J. A., Parlati, F., Fukuda, R., Johnston, R. J., Paz, K., Paumet, F., Söllner, T. H., and Rothman, J. E. (2000). Compartmental specificity of cellular membrane fusion encoded in SNARE proteins. Nature 408, 153-159.

Melia, S. M., Cole, E. S., and Turkewitz, A. P. (1998). Mutational analysis of regulated exocytosis in Tetrahymena. J. Cell Sci. 111, 131-140.

Merrifield, C. J., Feldman, M. E., Wan, L., and Almers, W. (2002). Imaging actin and dynamin recruitment during invagination of single clathrin-coated pits. Nature Cell Biol. 4, 691-698.

Meyer, M., Mayer, T., and Tiedtke, A. (1998). Maturation of phagosomes is accompanied by specific patterns of small GTPases. Electrophoresis 19, 2528-2535.

Mohamed, I., Klauke, N., Hentschel, J., Cohen, J., and Plattner, H. (2002). Functional and fluorochrome analysis of an exocytotic mutant yields evidence of store-operated $\mathrm{Ca}^{2+}$ influx in Paramecium. J. Membr. Biol. 187, 1-14.

Momayezi, M., Habermann, A. W., Sokolova, J. J., Kissmehl, R., and Plattner, H. (1993). Ultrastructural and antigenic preservation of a delicate structure by cryopreparation: Identification and immunogold localization during biogenesis of a secretory component (membrane-matrix connection) in Paramecium trichocysts. J. Histochem. Cytochem. 41, $1669-1677$. 
Momayezi, M., Kersken, H., Gras, U., Vilmart-Seuwen, J., and Plattner, H. (1986). Calmodulin in Paramecium tetraurelia: Localization from the in vivo to the ultrastructural level. $J$. Histochem. Cytochem. 34, 1621-1638.

Momayezi, M., Kissmehl, R., and Plattner, H. (2000). Quantitative immunogold localization of protein phosphatase 2B (calcineurin) in Paramecium cells. J. Histochem. Cytochem. 48, 1269-1281.

Morel, N., Synguelakis, M., and LeGal LaSalle, G. (1991). Detection with monoclonal antibodies of a $15-\mathrm{kDa}$ proteolipid in both presynaptic plasma membranes and synaptic vesicles in Torpedo electric organ. $J$. Neurochem. 56, 1401-1408.

Müller, O., Bayer, M. J., Peters, C., Andersen, J. S., Mann, M., and Mayer, A. (2002). The Vtc proteins in vacuole fusion: Coupling NSF activity to $\mathrm{V}_{0}$ trans-complex formation. $E M B O J$. 21, 259-269.

Nebenführ, A., Ritzenthaler, C., and Robinson, D. G. (2002). Brefeldin A: Deciphering an enigmatic inhibitor of secretion. Plant Physiol. 130, 1102-1108.

Neuwald, A. F., Aravind, L., Spouge, J. L., and Koonin, E. V. (1999). AAA+: A class of chaperone-like ATPases associated with the assembly, operation, and disassembly of protein complexes. Genome Res. 9, $27-43$.

Nickel, W., and Wieland, F. T. (1997). Biogenesis of COPI-coated transport vesicles. $F E B S$ Lett. 413, 395-400.

Nickel, W., Weber, T., McNew, J. A., Parlati, F., Söllner, T. H., and Rothman, J. E. (1999). Content mixing and membrane integrity during membrane fusion driven by pairing of isolated v-SNAREs and t-SNAREs. Proc. Natl. Acad. Sci. USA 96, 12571-12576.

Nilsson, J. R., and VanDeurs, B. (1983). Coated pits and pinocytosis in Tetrahymena. J. Cell Sci. 63, 209-222.

Orias, E., Flacks, M., and Satir, B. H. (1983). Isolation and ultrastructural characterization of secretory mutants of Tetrahymena thermophila. J. Cell Sci. 64, 49-67.

Palfrey, H. C., and Artalejo, C. R. (1998). Vesicle recycling revisited: Rapid endocytosis may be the first step. Neuroscience 83, 969-989.

Pape, R., and Plattner, H. (1985). Synchronous exocytosis in Paramecium cells. V. Ultrastructural adaptation phenomena during re-insertion of secretory organelles. Eur. $J$. Cell Biol. 36, 38-47.

Pape, R., and Plattner, H. (1990). Secretory organelle docking at the cell membrane of Paramecium cells: Dedocking and synchronized redocking of trichocysts. Exp. Cell Res. 191, 263-272.

Peters, C., Bayer, M. J., Bühler, S., Andersen, J. S., Mann, M., and Mayer, A. (2001). Transcomplex formation by proteolipid channels in the terminal phase of membrane fusion. Nature 409, 581-583.

Peters, C., and Mayer, A. (1998). $\mathrm{Ca}^{2+} /$ calmodulin signals the completion of docking and triggers a late step of vacuole fusion. Nature 396, 575-580.

Peterson, J. B. (1991). Small GTP-binding proteins associated with secretory vesicles of Paramecium. J. Protozool. 38, 495-501.

Plattner, H. (2002). My favorite cell-Paramecium. BioEssays 24, 649-658.

Plattner H. (Ed.) (1993). "Membrane Traffic in Protozoa." JAI Press, Greenwich, CT.

Plattner, H. (1987). Synchronous exocytosis in Paramecium cells. In "Cell Fusion" (A. E. Sowers, Ed.), pp. 69-98. Plenum Press, New York.

Plattner, H., and Kissmehl, R. (2003). Dense-core secretory vesicle docking and exocytotic membrane fusion in Paramecium cells. Biochim. Biophys. Acta. 1641, 185-193.

Plattner, H., and Klauke, N. (2001). Calcium in ciliated protozoa: Sources, regulation, and calcium regulated functions. Int. Rev. Cytol. 201, 115-208.

Plattner, H., Braun, C., and Hentschel, J. (1997). Facilitation of membrane fusion during exocytosis and exocytosis-coupled endocytosis and acceleration of "ghost" detachment in 
Paramecium by extracellular calcium: A quenched-flow/freeze-fracture analysis $J$. Membr. Biol. 158, 197-208.

Plattner, H., Habermann, A., Kissmehl, R., Klauke, N., Majoul, I., and Söling, H. D. (1997). Differential distribution of calcium stores in Paramecium cells: Occurrence of a subplasmalemmal store with a calsequestrin-like protein. Eur. J. Cell Biol. 72, 297-306.

Plattner, H., Knoll, G., and Pape, R. (1993). Synchronization of different steps of the secretory cycle in Paramecium tetraurelia: Trichocyst exocytosis, exocytosis-coupled endocytosis, and intracellular transport. In "Membrane Traffic in Protozoa" (H. Plattner, Ed.), pp. 123-148. JAI Press, Greenwich, CT.

Plattner, H., Pape, R., Haacke, B., Olbricht, K., Westphal, C., and Kersken, H. (1985). Synchronous exocytosis in Paramecium cells. VI. Ultrastructural analysis of membrane resealing and retrieval. J. Cell Sci. 77, 1-17.

Plattner, H., Reichel, K., Matt, H., Beisson, J., Lefort-Tran, M., and Pouphile, M. (1980). Genetic dissection of the final exocytosis steps in Paramecium tetraurelia cells: Cytochemical determination of $\mathrm{Ca}^{2+}$-ATPase activity over preformed exocytosis sites. J. Cell Sci. 46, 17-40.

Plattner, H., Westphal, C., and Tiggemann, R. (1982). Cytoskeleton-secretory vesicle interactions during the docking of secretory vesicles at the cell membrane in Paramecium tetraurelia cells. J. Cell Biol. 92, 368-377.

Pollack, S. (1974). Mutations affecting the trichocysts in Paramecium aurelia. I. Morphology and description of the mutants. J. Protozool. 21, 352-362.

Pouphile, M., Lefort-Tran, M., Plattner, H., Rossignol, M., and Beisson, J. (1986). Genetic dissection of the morphogenesis and dynamics of exocytosis sites in Paramecium. Biol. Cell 56, 151-162.

Quetglas, S., Iborra, C., Sasakawa, N., DeHaro, L., Kumakura, K., Sato, K., Leveque, C., and Seagar, M. (2002). Calmodulin and lipid binding to synaptobrevin regulates calciumdependent exocytosis. EMBO J. 21, 3970-3979.

Rappoport, J. Z., and Simon, S. M. (2003). Real-time analysis of clathrin-mediated endocytosis during cell migration. J. Cell Sci. 116, 847-855.

Rizo, J., and Südhof, T. C. (1998). Mechanics of membrane fusion. Nature Struct. Biol. 5, 839-842.

Rothman, J. E., and Söllner, T. H. (1997). Throttles and dampers: Controlling the engine of membrane fusion. Science 276, 1212-1213.

Ruiz, F., Beisson, J., Rossier, J., and Dupuis-Williams, P. (1999). Basal body duplication in Paramecium requires $\gamma$-tubulin. Curr. Biol. 9, 43-46.

Ruiz, F., Vayssié, L., Klotz, C., Sperling, L., and Madeddu, L. (1998). Homology-dependent gene silencing in Paramecium. Mol. Biol. Cell 9, 931-943.

Sankaranarayanan, S., and Ryan, T. A. (2000). Real-time measurements of vesicle-SNARE recycling in synapses of the central nervous system. Nature Cell Biol. 2, 197-204.

Sankaranarayanan, S., and Ryan, T. A. (2001). Calcium accelerates endocytosis of vSNAREs at hippocampal synapses. Nature Neurosci. 4, 129-136.

Sauer, M. K., and Kelly, R. B. (1995). Conjugation rescue of exocytosis mutants in Tetrahymena thermophila indicates the presence of functional intermediates in the regulated secretory pathway. J. Eukaryot. Microbiol. 42, 173-183.

Scales, S. J., Chen, Y. A., Yoo, B. Y., Patel, S. M., Doung, Y. C., and Scheller, R. H. (2000). SNAREs contribute to the specificity of membrane fusion. Neuron 26, 457-464.

Schrag, J. D., Procopio, D. O., Cygler, M., Thomas, D. Y., and Bergeron, J. J. M. (2003). Lectin control of protein folding and sorting in the secretory pathway. Trends Biochem. Sci. 28, 49-57.

Schroeder, C. C., Fok, A. K., and Allen, R. D. (1990). Vesicle transport along microtubular ribbons and isolation of cytoplasmic dynein from Paramecium. J. Cell Biol. 111, $2553-2562$. 
Sikora, J. (1981). Cytoplasmic streaming in Paramecium. Protoplasma 109, 57-77.

Skouri, F., and Cohen, J. (1997). Genetic approach to regulated exocytosis using functional complementation in Paramecium: Identification of the ND7 gene required for membrane fusion. Mol. Biol. Cell 8, 1063-1071.

Söllner, T., and Rothman, J. E. (1994). Neurotransmission: Harnessing fusion machinery at the synapse. Trends Neurosci. 17, 344-348.

Söllner, T., Bennett, M. K., Whiteheart, S. W., Scheller, R. H., and Rothman, J. E. (1993). A protein assembly-disassembly pathway in vitro that may correspond to sequential steps of synaptic vesicle docking, activation, and fusion. Cell 75, 409-418.

Söllner, T., Whiteheart, S. W., Brunner, M., Erdjument-Bromage, H., Geromanos, S., Tempst, P., and Rothman, J. E. (1993). SNAP receptors implicated in vesicle targeting and fusion. Nature 262, 318-324.

Sorkin, A. (2000). The endocytosis machinery. J. Cell Sci. 113, 4375-4376.

Sperling, L., Dessen, P., Zagulski, M., Pearlman, R. E., Migdalski, A., Gromadha, R., Froissard, M., Keller, A.-M., and Cohen, J. (2002). Random sequencing of Paramecium somatic DNA. Eukaryol. Cell 1, 341-352.

Sugita, S., Shin, O. H., Han, W., Lao, Y., and Südhof, T. C. (2002). Synaptotagmins form a hierarchy of exocytotic $\mathrm{Ca}^{2+}$ sensors with distinct $\mathrm{Ca}^{2+}$ affinities. $E M B O J \mathbf{2 1}, 270-280$.

Takai, Y., Sasaki, T., and Matozaki, T. (2001). Small GTP-binding proteins. Physiol. Rev. 81, 153-208.

Taniguchi, T., Mizuochi, T., Banno, Y., Nozawa, Y., and Kobata, A. (1985). Carbohydrates of lysosomal enzymes secreted by Tetrahymena pyriformis. J. Biol. Chem. 260, 13941-13946.

Tiedtke, A., Kiy, T., Vosskühler, C., and Rasmussen, L. (1993). Pathways of lysosomal enzyme secretion in Tetrahymena. In "Membrane Tarffic in Protozoa" (H. Plattner, Ed.), pp. 99-122. JAI Press, Greenwich, CT.

Tominaga, T., Allen, R. D., and Naitoh, Y. (1998). Cyclic changes in the tension of the contractile vacuole complex membrane control its exocytotic cycle. J. Exp. Biol. 201, 2647-2658.

Tooze, S. A., Martens, G. J. M., and Huttner, W. B. (2001). Secretory granule biogenesis: Rafting to the SNARE. Trends Cell Biol. 11, 116-122.

Traub, L. M., Kornfeld, S., and Ungewickell, E. (1995). Different domains of the AP-1 adaptor complex are required for Golgi membrane binding and clathrin recruitment. J. Biol. Chem. 270, 4933-4942.

Tse, S. M. L., Furuya, W., Gold, E., Schreiber, A. D., Sandvig, K., Inman, R. D., and Grinstein, S. (2003). Differential role of actin, clathrin, and dynamin in Fcy receptormediated endocytosis and phagocytosis. J. Biol. Chem. 278, 3331-3338.

Tucker, W. C., and Chapman, E. R. (2002). Role of synaptotagmin in $\mathrm{Ca}^{2+}$-triggered exocytosis. Biochem. J 366, 1-13.

Turkewitz, A. P., Madeddu, L., and Kelly, R. B. (1991). Maturation of dense core granules in wild type and mutant Tetrahymena thermophila. EMBO J 10, 1979-1987.

Turkewitz, A. P., Orias, E., and Kapler, G. (2002). Functional genomics: The coming of age for Tetrahymena thermophila. Trends Genet. 18, 35-40.

Uchiyama, K., Jokitalo, E., Kano, F., Murata, M., Zhang, X., Canas, B., Newman, R., Rabouille, C., Pappin, D., Freemont, P., and Kondo, H. (2002). VCIP135, a novel essential factor for $\mathrm{p} 97 / \mathrm{p} 47$-mediated membrane fusion, is required for Golgi and ER assembly in vivo. J. Cell Biol. 159, 855-866.

Urbé, S., Tooze, S. A., and Barr, F. A. (1997). Formation of secretory vesicles in the biosynthetic pathway. Biochim. Biophys. Acta 1358, 6-22.

Vayssié, L., Skouri, F., Sperling, L., and Cohen, J. (2000). Molecular genetics of regulated secretion in Paramecium. Biochimie 82, 269-288. 
Vogel, S. S., Blank, P. S., and Zimmerberg, J. (1996). Poisson-distributed active fusion complexes underlie the control of the rate and extent of exocytosis by calcium. J. Cell Biol. 134, 329-338.

Von Rueden, L., and Neher, E. (1993). A Ca-dependent early step in the release of catecholamines from adrenal chromaffin cells. Science 262, 1061-1065.

Vosskühler, C., and Tiedtke, A. (1993). Magnetic separation of phagosomes of defined age from Tetrahymena thermophila. J. Eukaryot. Microbiol. 40, 556-562.

Wassenegger, M. (2002). Gene silencing. Int. Rev. Cytol. 219, 61-113.

Watanabe, T., and Haga, N. (1996). Genetic characterization of the secretory mutants in Paramecium caudatum. Protoplasma 192, 11-19.

Weber, T., Parlati, F., McNew, J. A., Johnston, R. J., Westermann, B., Söllner, T. H., and Rothman, J. E. (2000). SNAREpins are functionally resistant to disruption by NSF and aSNAP. J. Cell Biol. 149, 1063-1072.

Whiteheart, S. W., Schraw, T., and Matveeva, E. A. (2001). $N$-Ethylmaleimide sensitive factor (NSF) structure and function. Int. Rev. Cytol. 207, 71-112.

Wilkens, S. (2001). Structure of the vacuolar adenosine triphosphatases. Cell Biochem. Biophys. 34, 191-208.

Xue, M., and Zhang, B. (2002). Do SNARE proteins confer specificity for vesicle fusion? Proc. Natl. Acad. Sci. USA 99, 13359-13361.

Yang. J. S., Lee, S. Y., Gao, M., Bourgoin, S., Randazzo, P. A., Premont, R. T., and Hsu, V. W. (2002). ARFGAP1 promotes the formation of COPI vesicles, suggesting function as a component of the coat. J. Cell Biol. 159, 69-78.

Zhang, F., Southwick, F. S., and Purich, D. L. (2002). Actin-based phagosome motility. Cell Motil. Cytoskel. 53, 81-88.

Zimmerberg. J. (2001). How can proteolipids be central players in membrane fusion? Trends Cell Biol. 11, 233-234. 